\title{
Development of strength and electrical properties of Al-Si-Mg casting aluminum alloys with an Mg content of $1 \mathrm{wt} \%$
}

\author{
Kształtowanie własności wytrzymałościowych i elektrycznych \\ odlewniczych stopów aluminium typu Al-Si-Mg \\ o zawartości magnezu na poziomie 1\% mas.
}

\begin{abstract}
Silumins (i.e., alloys where the main alloy additive is silicon) are the largest casting aluminum alloy group. Materials of this kind are characterized by high strength properties, high corrosion resistance, and low density, which make it possible to use them for construction purposes. A new group of developed properties typical for casting silumins are electrical and thermal conductivity. Thermal and electrical conductivity can be optimized by the suitable selection of chemical composition of the alloy, in the process of precipitation hardening, or by means of a combination of both. The present paper includes test results of the strength and electrical properties of AlSiMg casting aluminum alloys. The alloys that were subject to testing were AlSi5Mg1, AlSi7Mg1, and AlSi11Mg1. Heat treatment included homogenization at a temperature of $535^{\circ} \mathrm{C}$ over a time period of $8 \mathrm{~h}$, quenched, and artificial aging. The strength tests involved a Brinell hardness measurement as well as an electrical properties test involving electrical conductivity measurement tests.
\end{abstract}

Keywords: cast aluminum alloys, homogenization, quench, artificial aging, Brinell hardness, electrical conductivity

\section{Streszczenie}

Siluminy, czyli stopy aluminium z głównym dodatkiem stopowym w postaci krzemu, stanowią jedną z największych grup odlewniczych stopów aluminium. Materiały tego rodzaju charakteryzują się między innymi wysokimi własnościami wytrzymałościowymi, wysoką odpornością na działanie środowiska korozyjnego czy niskim ciężarem właściwym, co pozwala na ich stosowanie w celach konstrukcyjnych. Grupą własności odlewniczych stopów aluminium, nad którą aktualnie

Tadeusz Knych Prof. Ph.D. D.Sc. Eng., Justyna Wiecheć M.Sc. Eng., Piotr Uliasz Ph.D. Eng.: AGH University of Science and Technology, Faculty of Non-Ferrous Metals, Krakow, Poland; tknych@agh.edu.pl 
trwają intensywne badania są własności elektryczne oraz, powiązane z nimi, własności cieplne. Własności te można optymalizować przez odpowiedni dobór składu chemicznego stopów, wykorzystanie zjawiska utwardzania wydzieleniowego czy też w wyniku kombinacji obu metod. Niniejsza praca opisuje wyniki badań nad kształtowaniem własności wytrzymałościowych i elektrycznych odlewniczych stopów Al-Si-Mg. W badaniach wykorzystano trzy stopy o oznaczeniach AISi5Mg1, AlSi7Mg1 oraz AlSi11Mg1. Materiały zostały poddane operacjom obróbki cieplnej w postaci homogenizacji w temperaturze $535^{\circ} \mathrm{C}$ przed $8 \mathrm{~h}$, przesycaniu do wody oraz starzeniu sztucznemu. W ramach określenia własności wytrzymałościowych wykonano pomiary twardości analizowanych stopów przy użyciu metody Brinella. Własności elektryczne określono za pomocą pomiaru przewodności elektrycznej.

Słowa kluczowe: odlewnicze stopy aluminium, homogenizacja, przesycanie, starzenie sztuczne, twardość Brinella, przewodność elektryczna

\section{Introduction}

Aluminum alloys are used in foundry casting and, compared to other materials based on non-ferrous metals, are characterized by strength and at the same time low density, high electrical and thermal conductivity, high corrosion resistance, and very good casting properties [1]. Such a compilation of properties is allows to use Al-Si based alloys in the building and construction industries as well as the automotive and electricity industries [2].

Increasing strength and electrical properties of AISiMg alloys is possible through the selection of the appropriate chemical composition and/or through the appropriate heat treatment in line with the further use of the element. An increase in the silicon content in the Al-Si-Mg alloys leads to an increase in casting properties (the Si additive increases the castability and solidification of the alloy and prevents hot tears or hot cracks [3]) and increases strength properties [4]. High silicon content simultaneously decreases the plastic and electrical properties of silumins alloys [5]. Another significant alloy additive for this group of materials is magnesium. A high $\mathrm{Mg}$ content leads to an increase in strength properties and a decrease in the plastic properties of the alloy [6]. However, magnesium is introduced mainly for the purpose of obtaining better heat-treatment effectiveness.

Casting aluminum alloys have been in use for years; for this reason, there are numerous standardized specifications in the field. For instance, the European Standardization on casting aluminum alloys [7] specifies the required mechanical properties (hardness, tensile strength) dependent on the hardening type (a detailed description of which is set out in Table 1).

Figure 1 presents an overview of standard strength properties in the forms of electrical conductivity and Brinell hardness [7, 8]. The majority of classic casting aluminum alloys are made for construction applications where high strength of materials is required - area I of the graph. On the other hand, only pure aluminum (which is obvious) and tin alloys are characterized by high electrical conductivity - area IV of the graph. So far, there have been no material solutions in the field of standard casting aluminum alloys that are characterized by both high strength properties and, at the same time, high electrical 
conductivity - area II of the graph. Reaching the range of high hardness - high conductivity is possible through the selection of suitable chemical composition and heat treatment processes $[9,10]$.

Table 1. Temper designations of aluminum casting alloys according [7]

\begin{tabular}{|c|c|}
\hline Symbol & Operation type \\
\hline $\mathrm{F}$ & As cast \\
\hline 0 & Annealed \\
\hline T1 & Controlled cooling from casting and naturally aged \\
\hline T4 & Solution heat treated and naturally aged where applicable \\
\hline T5 & Controlled cooling from casting and artificially aged or over-aged \\
\hline T6 & Solution heat treated and fully artificially aged \\
\hline T64 & Solution heat treated and artificially under-aged \\
\hline T7 & Solution heat treated and artificially over-aged (stabilized) \\
\hline
\end{tabular}

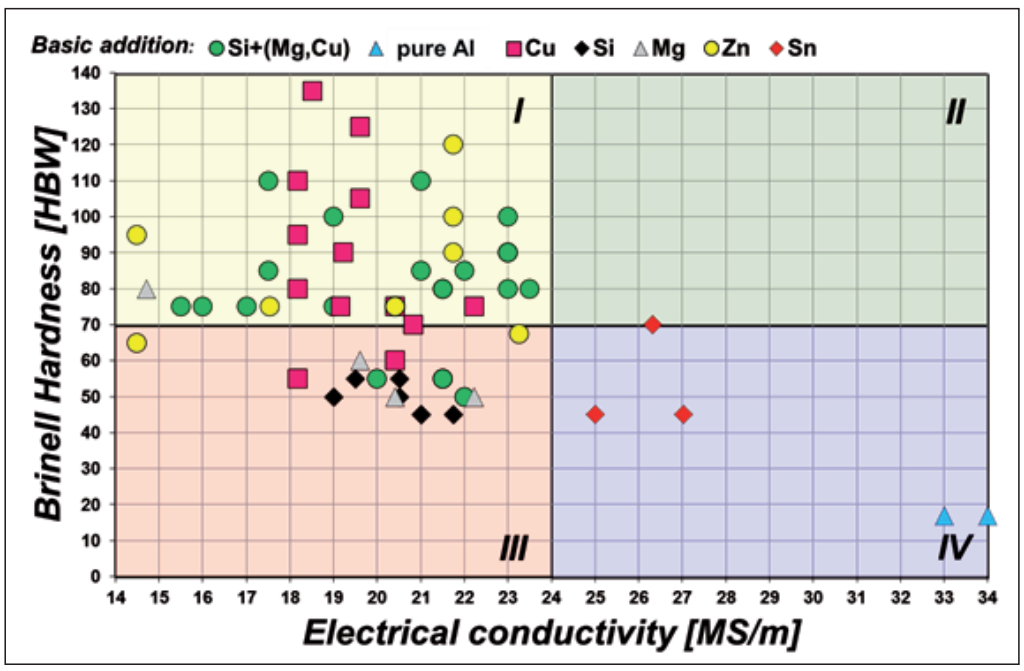

Fig. 1. Relation between Brinell hardness and electrical conductivity for traditional casting aluminum alloys $[9,10]$

\section{Characteristics of the tested alloys}

This paper presents tests for three casting aluminum alloys with a silicon content of 5, 7 and $11 \mathrm{wt} \%$ as well as a magnesium content of approximately $1 \mathrm{wt} \%$. The chemical composition of the tested materials is presented in Table 2 . The alloys have been made through permanent mold casting and (following crystallization) cooled in the open air. 
Table 2. Chemical composition of the investigated alloys

\begin{tabular}{|c|c|c|c|c|c|c|c|c|}
\hline \multirow{2}{*}{ Symbol alloy } & \multicolumn{8}{|c|}{ Element, wt\% } \\
\cline { 2 - 9 } & $\mathbf{S i}$ & $\mathbf{M g}$ & $\mathbf{F e}$ & $\mathbf{C u}$ & $\mathbf{T i}$ & $\mathbf{V}$ & $\mathbf{C r}$ & $\mathbf{A l}$ \\
\hline AlSi5Mg1 & 5.181 & 0.990 & 0.118 & 0.002 & 0.007 & 0.010 & 0.002 & remainder \\
\hline AlSi7Mg1 & 7.234 & 0.947 & 0.130 & 0.002 & 0.007 & 0.009 & 0.002 & remainder \\
\hline AlSi11Mg1 & 11.392 & 1.135 & 0.197 & 0.002 & 0.007 & 0.009 & 0.003 & remainder \\
\hline
\end{tabular}

Figures 2 and 3 present an overview of the strength properties (Brinell hardness) and electrical properties (electrical conductivity) of the tested alloys in the F temper.

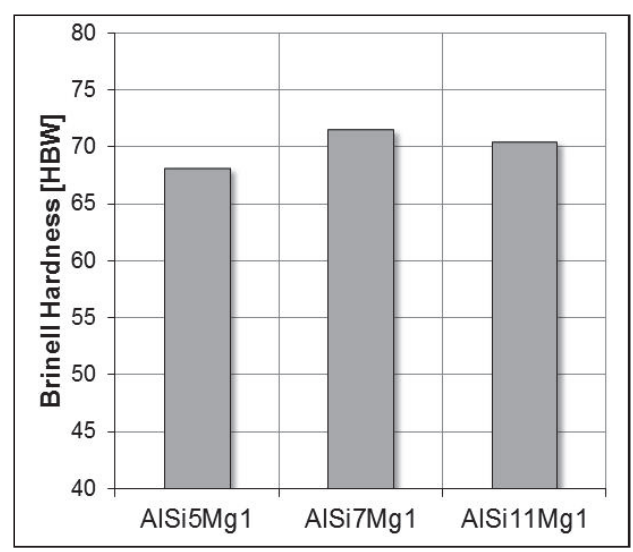

Fig. 2. Brinell hardness of the investigated materials (as cast temper)

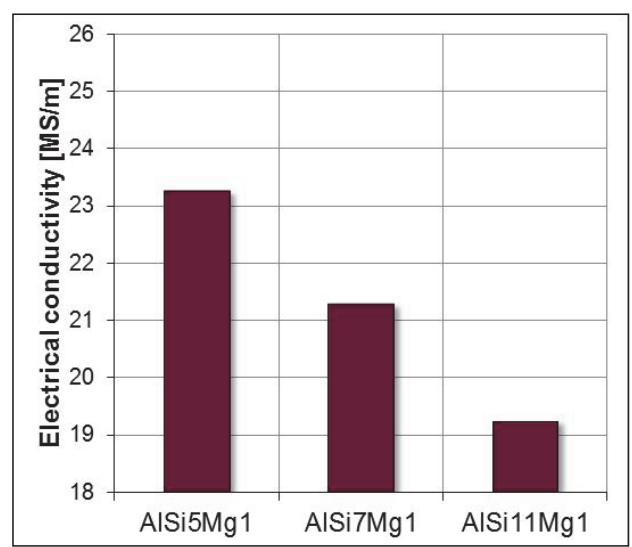

Fig. 3. Electrical conductivity of the investigated materials (as cast temper)

\section{Program and testing methods}

The tested materials were subject to heat treatment operations in the form of solution heat treatment, which resulted in the T4 temper (solution heat treatment conditions: $535^{\circ} \mathrm{C} / 8 \mathrm{~h}$ - material cooled down with water at a temperature of $25^{\circ} \mathrm{C}$ ). Next, the alloys underwent an artificial aging operation at a temperature range of 140 to $240^{\circ} \mathrm{C}$ in a time period of $24 \mathrm{~h}$. For all of the variants of the heat treatment operation, Brinell hardness and electrical conductivity were carried out. The hardness tests were performed on an HPO-250 WPM Leipzig hardness tester. Electrical conductivity of the tested alloys was measured with a SIGMATEST ${ }^{\oplus}$ measuring device, using the eddy currents method induced in the tested material. Each of the measuring points presented in the paper is an arithmetic mean of at least three measurements in the case of Brinell hardness and at least ten measurements in the case of electrical conductivity. 


\section{Test results}

The test results for the AlSi5Mg1 alloy are presented below. Figure 4 shows the alloy microstructures for the T6 temper. Brinell hardness over an artificial aging time is shown in Figure 5. Figure 6 presents the results of the electrical conductivity measurements.
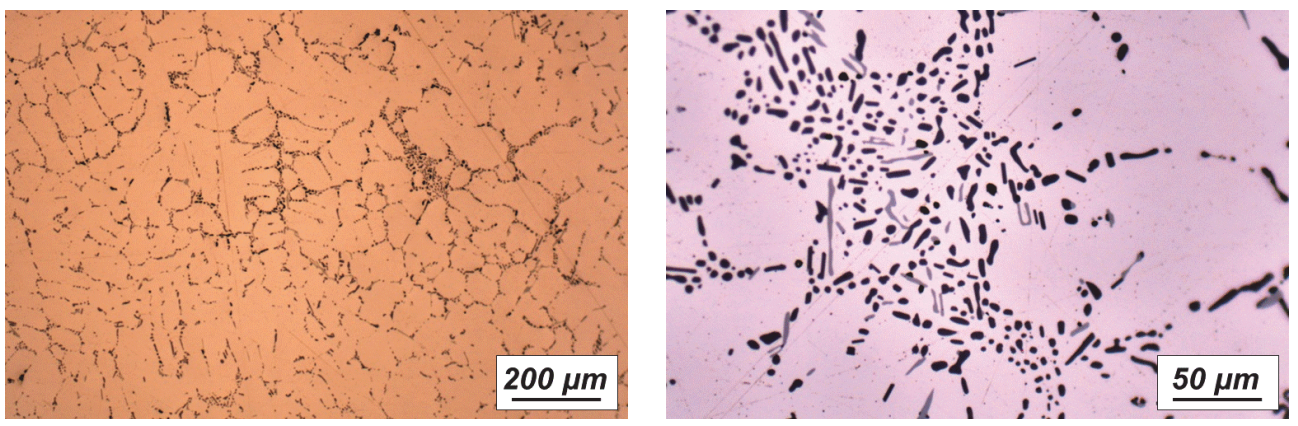

Fig. 4. Microstructures of the AlSi5Mg1 alloy for the T6 temper

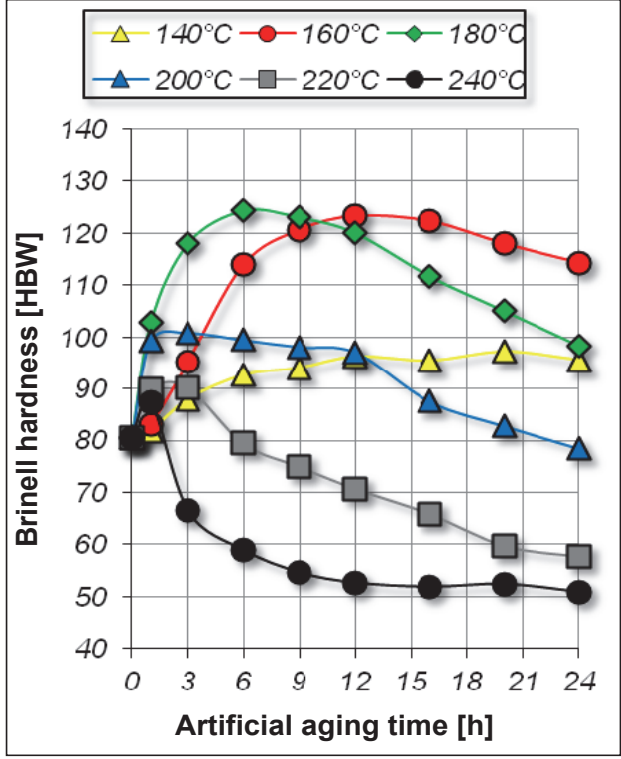

Fig. 5. Brinell hardness versus temperature and time of artificial aging for AlSi5Mg1 alloy

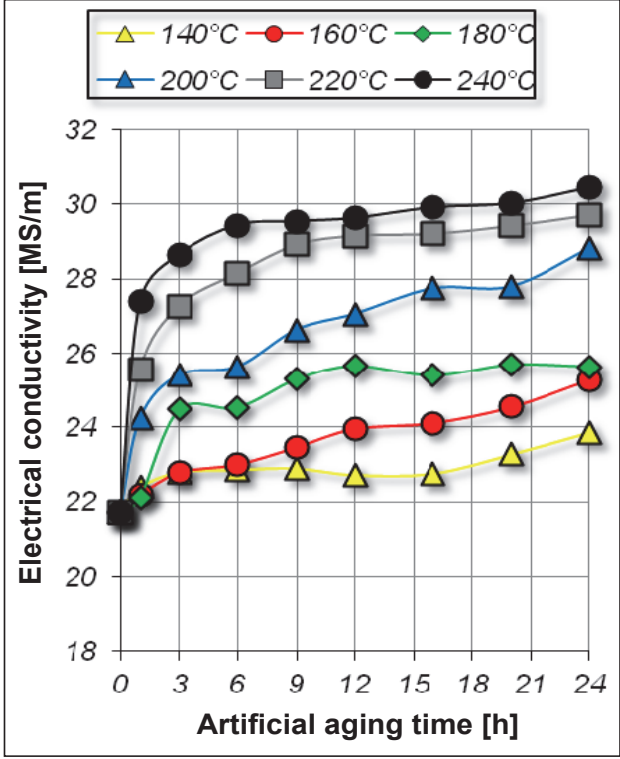

Fig. 6. Electrical conductivity versus temperature and time of artificial aging for AISi5Mg1 alloy

The maximum hardness for the AISi5Mg1 alloy was observed in the case of artificial aging at a temperature of $180^{\circ} \mathrm{C}$ for $6 \mathrm{~h}$, and this amounted to $124.33 \mathrm{HBW}$ (an increase of over $70 \%$ as compared to the properties of the T4 temper). Lowering the artificial 
aging temperature to $160^{\circ} \mathrm{C}$ extended the time needed to obtain the maximum hardness (123.33 HBW), but further lowering of the temperature would not make it possible to carry out the heat treatment effective from the point of view of the strength properties - the maximum hardness level for aging at a temperature of $140^{\circ} \mathrm{C}$ in the tested time is $97.13 \mathrm{HBW}$. In the case of a temperature of $200^{\circ} \mathrm{C}$, the maximum Brinell hardness was obtained for a time of $3 \mathrm{~h}$ ( $100.83 \mathrm{HBW}$ - an increase of nearly $33 \%$ as compared to the T4 temper).

In the case of the AISi5Mg1 alloy following heat treatment of the T6/T7 temper, two groups of curves for electrical conductivity over an artificial aging time were observed: curves exceeding the $26 \mathrm{MS} / \mathrm{m}$ (temperatures of $200-240^{\circ} \mathrm{C}$ ), and curves equal with the temperatures in which the level of $26 \mathrm{MS} / \mathrm{m}$ was obtained in the analyzed scope of artificial aging times (temperatures of $140-180^{\circ} \mathrm{C}$ ). In the case of the first group of curves, the maximum points for the particular temperatures of artificial aging reached a level of approximately $30.5 \mathrm{MS} / \mathrm{m}$ for a temperature of $240^{\circ} \mathrm{C}$ (an increase of approx. $40 \%$ as compared to the T4 temper) and approx. $30 \mathrm{MS} / \mathrm{m}$ for a temperature of $220^{\circ} \mathrm{C}$ (an increase of approx. 33\% as compared to the T4 temper). In the case of the other group of curves, the maximum electrical conductivity level was also reached for artificial aging for $24 \mathrm{~h}$ and for temperatures of $180^{\circ} \mathrm{C}$ and $160^{\circ} \mathrm{C}$, amounting to approx. 26 and $25 \mathrm{MS} / \mathrm{m}$ respectively. In the case of the lowest temperature $\left(140^{\circ} \mathrm{C}\right)$ and $24 \mathrm{~h}$ of aging, an level electrical conductivity of over $24 \mathrm{MS} / \mathrm{m}$ was not crossed.

Another group of results are the analyses concerning research into the AlSi7Mg1 alloy heat treatment. Figure 7 presents the microstructures of this material in the T6 temper. Figures 8 and 9 show the measurement results for Brinell hardness and electrical conductivity (respectively) for various parameters of the artificial aging operation.
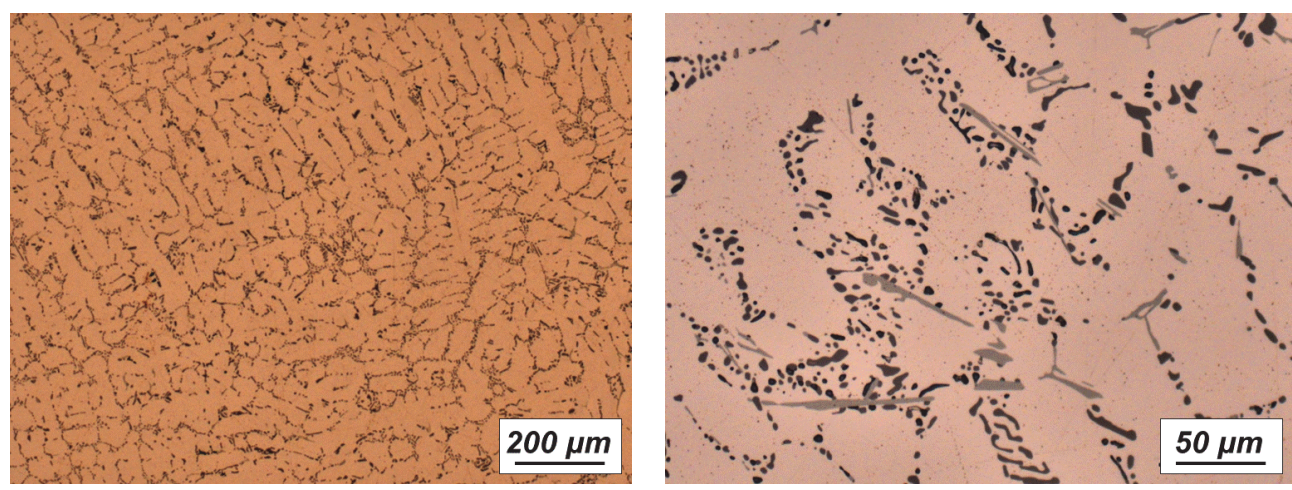

Fig. 7. Microstructures of the AISi7Mg1 alloy for the T6 temper

Looking at the artificial aging curves for the AISi7Mg1 alloy, it can be observed that the highest obtained levels of Brinell hardness for the particular annealing temperatures were: $126 \mathrm{HBW}$ for artificial aging at a temperature of $160^{\circ} \mathrm{C}$ for $12 \mathrm{~h}$ (an increase in hard- 
ness by approx. $52 \%$ as compared to the T4 temper), $126.67 \mathrm{HBW}$ for artificial aging at a temperature of $180^{\circ} \mathrm{C}$ for $6 \mathrm{~h}$ (an increase by approx. 53\%), and for temperatures of $200^{\circ} \mathrm{C}, 220^{\circ} \mathrm{C}$, and $240^{\circ} \mathrm{C}$, respectively, for the artificial aging for $1 \mathrm{~h}: 117.33$ (an increase of approx. 42\%), 113.33 (an increase of approx. 37\%), and 85.6 HBW (an increase of approx. $4 \%$ ). For a temperature of $140^{\circ} \mathrm{C}$, the highest hardness was obtained for the longest artificial aging time, and this level amounted to $108.63 \mathrm{HBW}$ (i.e., an increase of approx. $31 \%$ as compared to the T4 temper for the AISi7Mg1 alloy).

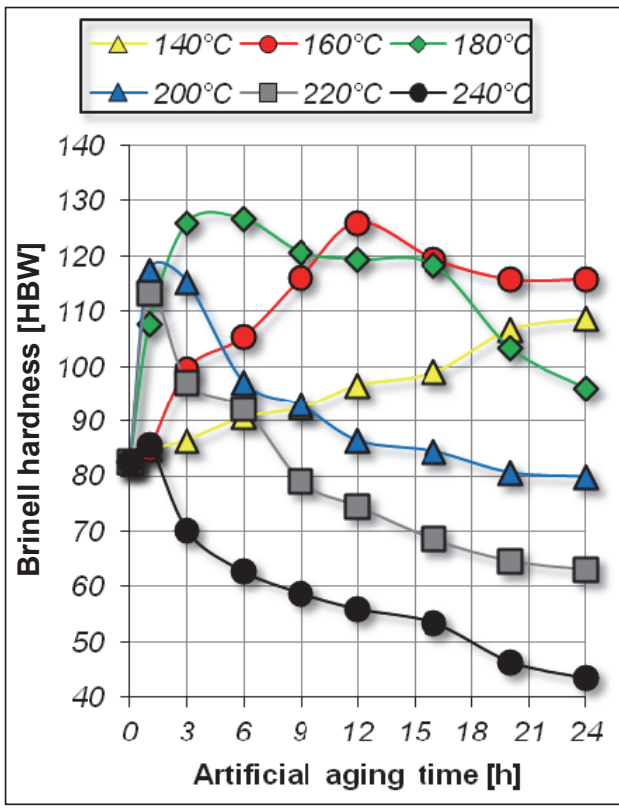

Fig. 8. Brinell hardness versus temperature and time of artificial aging for AISi7Mg 1 alloy

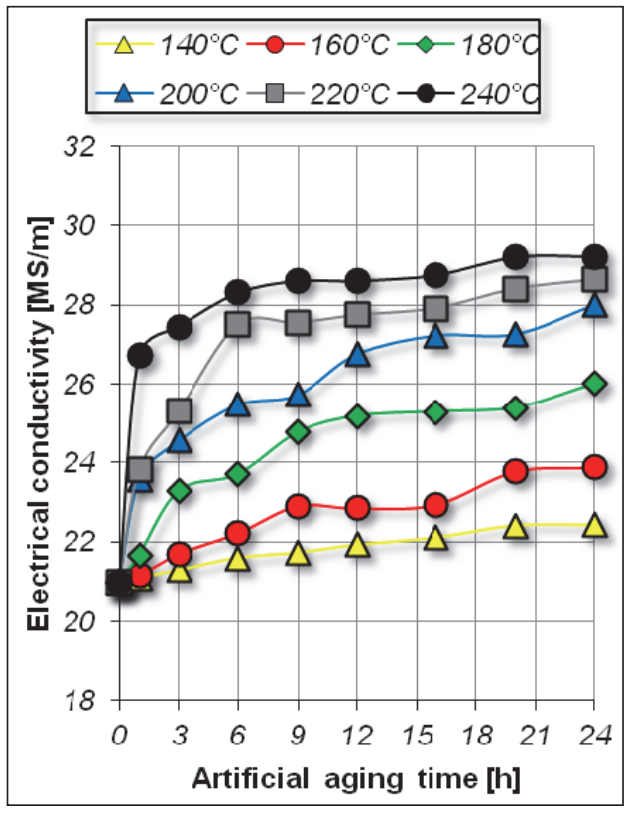

Fig. 9. Electrical conductivity versus temperature and time of artificial aging for AlSi7Mg1 alloy

The maximum electrical conductivity level for the AISi7Mg1 alloy was obtained after annealing at a temperature of $240^{\circ} \mathrm{C}$ for $24 \mathrm{~h}(29.23 \mathrm{MS} / \mathrm{m})$. In both cases of artificial aging at temperatures of $240^{\circ} \mathrm{C}$ and $220^{\circ} \mathrm{C}$ after $9 \mathrm{~h}$ of annealing, the area of maximum electrical conductivity was obtained (respectively, ranges of $28.3-29.3 \mathrm{MS} / \mathrm{m}$ and $27.5-28.6 \mathrm{MS} / \mathrm{m}$ ) where, together with an increase in the time of the process, the level of electrical properties rose slightly. For artificial aging at temperatures of $200^{\circ} \mathrm{C}$ and $180^{\circ} \mathrm{C}$, the level of high and stable electrical properties was obtained after as much as $12 \mathrm{~h}$ and involved ranges of $26.7-28 \mathrm{MS} / \mathrm{m}$ and $25.20-26 \mathrm{MS} / \mathrm{m}$ respectively, which are the maximum points for these temperatures allowed to obtain electrical conductivity higher than the conductivity obtained for the T4 temper by 32 and $23 \%$. At a temperature of $140^{\circ} \mathrm{C}$, electrical properties after $24 \mathrm{~h}$ of annealing increased by only $6.5 \%$. 
The last alloy discussed in the paper is the AlSi11Mg1 material. Microstructures of this material are presented in Figure 10 (T6 temper). An overview of the Brinell hardness and electrical conductivity results is presented in Figures 11 and 12.
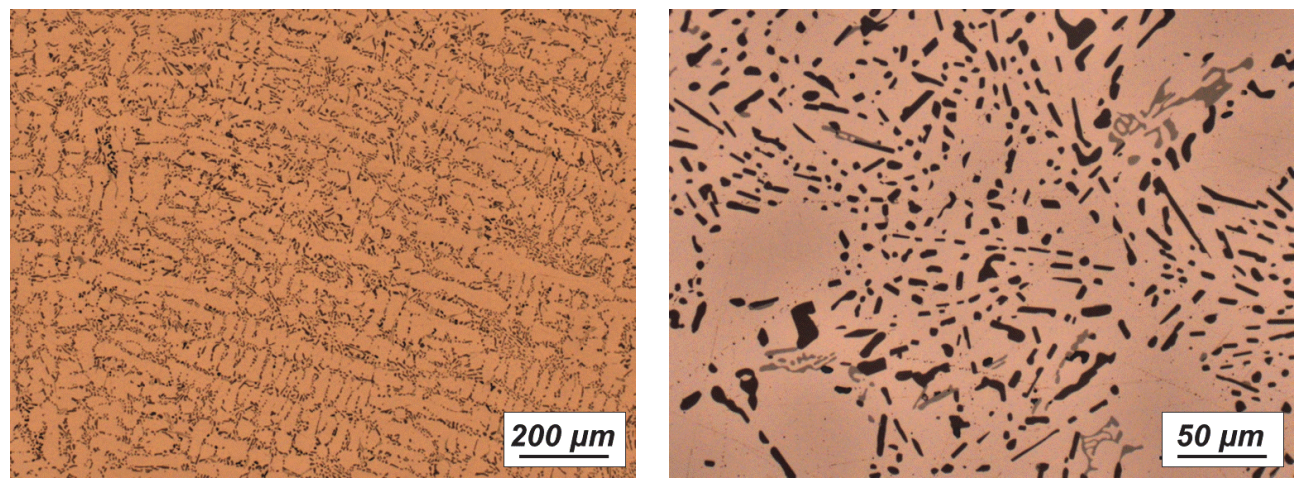

Fig. 10. Microstructures of the AlSi11Mg1 alloy for the T6 temper

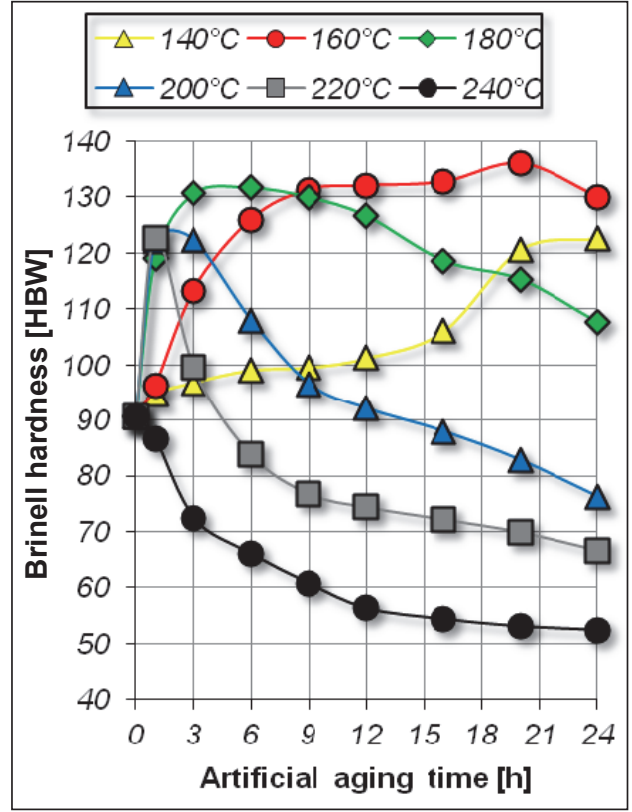

Fig. 11. Brinell hardness versus temperature and time of artificial aging for AISi11Mg1 alloy

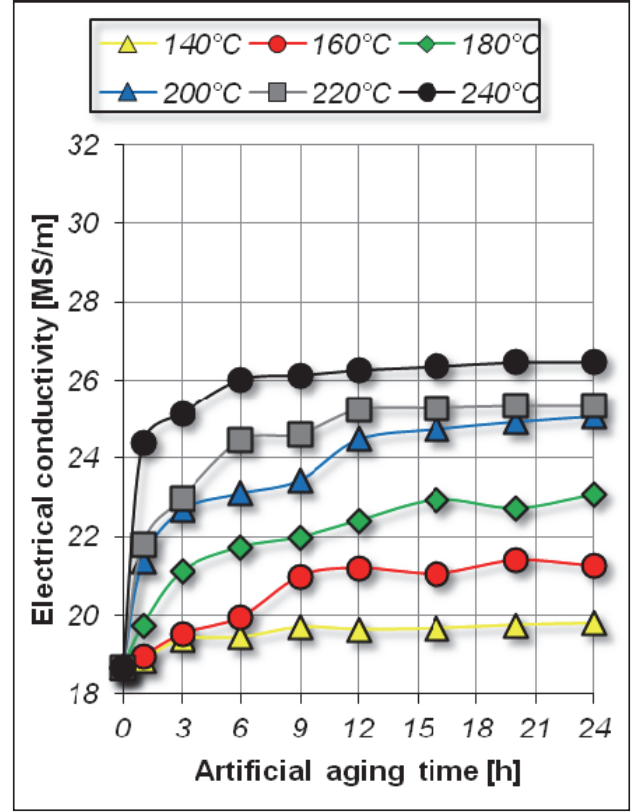

Fig. 12. Electrical conductivity versus temperature and time of artificial aging for AlSi11 Mg1 alloy

A further increase of silicon content to a level of approx. 11\% mass allowed us to raise the maximum Brinell hardness value to a level of $136 \mathrm{HBW}$ after artificial aging at a temperature of $160^{\circ} \mathrm{C}$ for $20 \mathrm{~h}$ (an increase of approx. $50 \%$ as compared to the T4 
temper). Raising the temperature to $180^{\circ} \mathrm{C}$ made it possible to obtain a level of $130 \mathrm{HBW}$ already after $3 \mathrm{~h}$ of artificial aging, which (in the case of artificial aging at a temperature of $160^{\circ} \mathrm{C}$ ) was possible after as long as $9 \mathrm{~h}$. A further increase in the temperature for the process to be carried out has no beneficial effect on the strength properties in the form of Brinell hardness: at a temperature of $200^{\circ} \mathrm{C}$ following reaching the maximum point for approx. $122 \mathrm{HBW}$ after a time of 1-3 h, a steady drop in hardness was observed of approx. $76 \mathrm{HBW}$ after $24 \mathrm{~h}$. A similar level of maximum hardness was observed for a temperature of $220^{\circ} \mathrm{C}$ and $1 \mathrm{~h}$ aging; however, in this case, the material was artificially aged faster and reached a lower value (approx. $66 \mathrm{HBW}$ after $24 \mathrm{~h}$ ). In the case of artificial aging at a temperature of $140^{\circ} \mathrm{C}$, an increase in Brinell hardness to a level of slightly over $120 \mathrm{HBW}$ was observed after aging longer then $16 \mathrm{~h}$.

The maximum electrical conductivity obtained for AlSi11Mg1 amounted to approx. $26.5 \mathrm{MS} / \mathrm{m}$ (an increase of approx. $42 \%$ as compared to the T4 temper). A satisfactory level of electrical conductivity was also obtained for artificial aging at temperatures of $220^{\circ} \mathrm{C}$ and $200^{\circ} \mathrm{C}$. The level of $24 \mathrm{MS} / \mathrm{m}$ in these cases was exceeded after 6 and $12 \mathrm{~h}$, respectively. In the case of a temperature of $180^{\circ} \mathrm{C}$, the maximum hardness level following artificial aging for $24 \mathrm{~h}$ was approx. $23 \mathrm{MS} / \mathrm{m}$. For lower temperatures $140-160^{\circ} \mathrm{C}$, the artificial aging curves did not exceed a level of $22 \mathrm{MS} / \mathrm{m}$.

\section{Conclusions}

The conducted tests and analyses led to the following conclusions:

- The AISi5Mg1, AlSi7Mg1, and AISi11Mg1 alloys in the F and T4 state display average strength properties and electrical properties from the viewpoint of their further application.

- The parameters of the artificial aging operation for which both high Brinell hardness (over $70 \mathrm{HBW}$ ) and high electrical conductivity (over $24 \mathrm{MS} / \mathrm{m}$ ) was obtained are:

- for the AlSi5Mg1 alloy: $160^{\circ} \mathrm{C} / 16-24 \mathrm{~h}, 180-200^{\circ} \mathrm{C} / 3-24 \mathrm{~h}, 220^{\circ} \mathrm{C} / 1-12 \mathrm{~h}$, $240^{\circ} \mathrm{C} / 1 \mathrm{~h}$;

- for the AlSi7Mg1 alloy: $180^{\circ} \mathrm{C} / 9-24 \mathrm{~h}, 200^{\circ} \mathrm{C} / 3-24 \mathrm{~h}, 220^{\circ} \mathrm{C} / 1-3 \mathrm{~h}$;

- for the AlSi11Mg1 alloy: $200^{\circ} \mathrm{C} / 12-4 \mathrm{~h}, 220^{\circ} \mathrm{C} / 6-16,240^{\circ} \mathrm{C} / 1-3$.

- An increase in the silicon content in the alloy leads to its increase in hardness with a simultaneous degradation of its electrical conductivity.

- The eutectic of silicon becomes slightly oval following artificial aging as compared to the structure obtained for the T4 temper.

\section{References}

[1] Totten G.E., MacKenzie D.S.: Handbook of Aluminum. Volume 1: Physical Metallurgy and Processes. MARCEL DEKKER, New York 2003

[2] Polmer I.J.: Light Alloys. From Traditional Alloys to Nanocrystals. Elsevier 2006

[3] Hatch J.E.: Aluminum Properties and Physical Metallurgy. ASM 1984 
[4] Kaufman J.G., Rooy E.R.: Aluminum Alloy Castings. Properties, Processes and Applications. ASM International 2004

[5] Mulazimoglu M.H., Drew R.A.L., Gruzelski J.E.: Electrical conductivity of aluminium-rich Al-Si-Mg alloys. Journal of Materials Science Letters, 8 (1989), 297-300

[6] Yıldırım M., Ozyurek D.: The effects of Mg amount on the microstructure and mechanical properties of Al-Si-Mg alloys. Materials and Design, 51 (2013), 767-774

[7] PN-EN 1706: 2011 Aluminium i stopy aluminium - Odlewy - Skład chemiczny i własności mechaniczne [Aluminium and aluminium alloys - Castings - Chemical composition and mechanical properties]

[8] http://www.totalmateria.com [1.05.2015]

[9] Wiecheć J., Uliasz P., Knych T., Piwowarska-Uliasz M.: Odlewnicze stopy aluminium typu AlSiMg przeznaczone na cele elektryczne. Rudy i Metale Nieżelazne, 6 (2013), 333-338

[10] Wiecheć J., Uliasz P., Knych T., Piwowarska-Uliasz M., Jarosz R.: The influence of chemical composition and parameters of heat treatment on the mechanical properties and electrical conductivity in hypoeutectic aluminium silicon alloys. Archives of Foundry Engineering, 13, 3 (2013), 179-184

The Statutory Activities no 15.11.180.812 support this work 